\title{
Teaching with Children's Literature in Initial Teacher Education: Developing Equitable Literacy Pedagogy through Talk about Books
}

\author{
Enseñar con literatura infantil en la formación inicial de maestros/as: \\ desarrollo de una pedagogía de la literacidad equitativa a través del \\ diálogo sobre libros
}

\author{
Ensenyar amb literatura infantil en la formació inicial de mestres: \\ desenvolupament d'una pedagogia de la literacitat equitativa a través \\ del diàleg sobre llibres
}

Alyson Simpson. University of Sydney, Australia. alyson.simpson@sydney.edu.au

https://orcid.org/0000-0003-3700-4585

\begin{abstract}
Teaching about children's literature in pre-service teacher education is quite rare, even though research shows it is crucial for teachers to be good at teaching reading as well as being committed readers (Commeyras et al., 2003; Cremin et al., 2009). Emphasis on the reading process can sideline the importance of talking about quality literature to engage students in reading (Simpson, 2016). I have positioned the role of talk about books as a core part of the undergraduate program that I coordinate. In this way, the preservice teachers of this study were alerted about the 'fiction effect' (Jerrim \& Moss, 2019), which shows extended reading of literature has potential to improve reading skills for all students.

The paper explores how an initial teacher education course in Australia partnered with local schools to create interactions between school children and pre-service teachers talking about children's literature. A dialogic approach to learning (Alexander, 2020) was adopted to teaching pre-service teachers to develop equitable literacy pedagogy working with children's literature. Equity was used as a guiding principle to ensure pre-service teachers would provide children of all backgrounds and abilities the same opportunities to read literary texts. During their education program, the pre-service teachers received letters from school children who wrote about their reading preferences. The letters were discussed for evidence of reading habits and new books were sought as recommendations for children to read. By considering their own reading identities, pre-service teachers collectively developed their knowledge about children's literature as they developed knowledge of literacy pedagogy. The scaffolding of habits of noticing through iterative discussion (Simpson et al., 2020) helped the pre-service teachers learn about their students, learn from their students, and encouraged them to take a more holistic view of the teaching of reading.
\end{abstract}

Keywords: children's literature, equity, literacy, dialogic pedagogy, initial teacher education 


\section{Resumen}

Enseñar literatura infantil en la formación de docentes es bastante extraño, aunque las investigaciones muestran que es crucial, para maestros y maestras, ser competentes en la enseñanza de la lectura y también ser lectores y lectoras comprometidos (Commeyras et al., 2003; Cremin et al., 2009). El énfasis en el proceso lector puede dejar de lado la importancia de hablar sobre literatura de calidad que anime al alumnado a leer (Simpson, 2016). Hemos situado el rol de hablar sobre libros como una parte fundamental del programa de graduados que coordinamos. De esta manera, se advirtió al estudiantado de Magisterio de este estudio sobre el "efecto ficción" (Jerrim \& Moss, 2019) el cual muestra que la lectura extensiva de literatura tiene potencial para mejorar las destrezas lectoras para todo el alumnado.

Este artículo explora la colaboración entre un curso de educación inicial para maestros en Australia con escuelas locales para crear interacciones entre escolares y estudiantes de Magisterio hablando sobre literatura infantil. Se adoptó un enfoque dialógico al aprendizaje (Alexander, 2020) para enseñar a desarrollar una pedagogía equitativa de la literacidad al alumnado de Magisterio trabajando con literatura infantil. La equidad se utilizó como principio guía para asegurar que este alumnado proveería en un futuro a niños y niñas de todos los contextos y con diferentes habilidades las mismas oportunidades de leer textos literarios. Durante su programa educativo, el alumnado de Magisterio recibió cartas de escolares que escribían sobre sus preferencias lectoras. Las cartas se discutieron para mostrar los hábitos lectores y se buscaron nuevos libros para recomendar a los escolares como lectura. Considerando los propios perfiles lectores, el alumnado de Magisterio desarrolló colectivamente su conocimiento sobre literatura infantil y también su conocimiento sobre pedagogía de la literacidad. Crear hábitos de percepción a través de discusiones iterativas (Simpson et al., 2020) ayudó al estudiantado a aprender sobre los y las escolares, aprender de los y las escolares y les animó a tomar un punto de vista más holístico en la enseñanza de la lectura.

Palabras clave: literatura infantil, equidad, literacidad, pedagogía dialógica, formación de maestros

\section{Resum}

Ensenyar literatura infantil en la formació de mestres és bastant estrany, encara que la recerca mostra que és crucial, per als i les mestres, tant ser competent en l'ensenyament de la lectura com ser lectors/es compromesos (Commeyras et al., 2003; Cremin et al., 2009). L'èmfasi en el procés lector pot deixar de banda la importància de parlar sobre literatura de qualitat que encoratge l'estudiantat a llegir (Simpson, 2016). Hem situat el rol de parlar al voltant de llibres com una part fonamental del programa de graduats que coordinem. D'aquesta manera, l'estudiantat de Magisteri d'aquest estudi estaven advertits sobre l"efecte ficció" (Jerrim \& Moss, 2019), el qual mostra que la lectura extensiva de literatura té potencial per millorar les destreses lectores per a tot l'alumnat.

Aquest article explora la col-laboració entre un curs d'educació inicial per a mestres a Austràlia amb escoles locals per crear interaccions entre escolars i estudiants de Magisteri tot parlant sobre literatura infantil. Es va adoptar un acostament dialògic a l'aprenentatge (Alexander, 2020) per ensenyar a desenvolupar una pedagogia equitativa de la literacitat a l'alumnat de Magisteri treballant amb literatura infantil. L'equitat es va utilitzar com a principi guia per tal d'assegurar que aquest alumnat proveirien en un futur a infants de tots els contextos i amb diferents habilitats, les mateixes oportunitats de llegir textos literaris. Durant el seu programa educatiu, l'alumnat de Magisteri va rebre cartes d'escolars que escrivien sobre les seues preferències lectores. Les cartes van ser discutides per mostrar els hàbits lectors i es van buscar nous llibres per tal de recomanar als infants com a lectura. Tot considerant els propis perfils lectors, l'alumnat de Magisteri va desenvolupar col-lectivament el seu coneixement sobre literatura infantil i també el seu coneixement sobre pedagogia de la literacitat. El fet de bastir hàbits de percebre a través de les discussions iteratives (Simpson et al., 2020) va ajudar l'estudiantat a aprendre sobre els escolars, aprendre també dels seus escolars i els va encoratjar a prendre un punt de vista més holístic sobre l'ensenyament de la lectura.

Parales clau: literatura infantil, equitat, literacitat, pedagogia dialògica, formació de mestres 


\section{Introduction}

Equitable access to literature is core to student development. Research such as the Progress in International Reading Literacy Study (PIRLS) reports demonstrates that children from poorly resourced homes are less likely to achieve successful learning outcomes at school. That is, there is a proportionate relationship between the number of books students have at home and the reading scores they achieve, so those with more books at home have a distinct learning advantage over those with few (Thomson et al., 2016). The same research shows the power of teachers who provide opportunities for extended engagement with literary texts on a regular basis, as this builds inclusive practices that support all students to achieve equitable learning outcomes. Despite the importance of [...]it is crucial that the deliberative decisions teachers make to improve student learning outcomes in general are informed by disciplinary content knowledge about literary texts, pedagogic content knowledge about the teaching of reading, as well as situated knowledge about their students and themselves as readers. engaging all students in reading for enjoyment, struggling readers are more often given skills-based exercises than opportunities to read and talk about literary texts with their peers (Simpson, 2016). The PIRLS framework underscores the continuing need for teachers to be well versed, not only in what they teach and how they teach, including $21^{\text {st }}$-century modes of learning, but also to have good insight into their learners' needs (Mullis et al., 2009). The concept of teacher as professional, therefore, must encompass the capacity for them to orchestrate multiple sources of evidence informed by research (Ellis \& Rowe, 2020). Hence, it is crucial that the deliberative decisions teachers make to improve student learning outcomes in general are informed by disciplinary content knowledge about literary texts, pedagogic content knowledge about the teaching of reading (Shulman, 2015), as well as situated knowledge about their students and themselves as readers.

This paper reports on a study of an initial teacher education course in Australia that prompted discussions of children's literature between school children and pre-service teachers (PST) as a pedagogic tool. The purpose of the program was to use a dialogic approach that supports the coconstruction of meaning through well structured, collaborative talk (Alexander, 2020) to teach preservice teachers to develop equitable literacy pedagogy informed by children's literature. During the final unit studying English in their undergraduate education degree, the PST received letters from school children who wrote about their reading preferences. As part of their coursework, the PST discussed the children's letters and reading habits, planned a sequence of lessons to encourage their critical reading, and sought new reading recommendations. The PST also wrote biographies about their own reading practices at the start and end of the semester. Because of these interconnected 
activities, the PST collectively developed their knowledge about children's literature as they expanded their personal and professional knowledge of literacy pedagogy. Prior research has shown that iterative discussions help PST learn about and from their students, and encourages them to take a more holistic view of the teaching of reading with children's literature (Simpson, 2020).

\section{Literature Review}

The literature review introduces three key bodies of work that influence this study. Each one contributes to the theoretical and methodological design of the research in different ways. The three interrelated areas align with the thematic analysis of data to highlight how: a social equity agenda drives professional decision making; personal engagement with children's literature informs teaching; and pedagogic rationales can be strengthened through the adoption of dialogic learning.

\subsection{Equitable support of students}

A culture of learning by testing is strongly prevalent in schools (Ellis \& Smith, 2017). The tragic result, as Graves (2002) called it, of this approach is "the proliferation of aliterate children, who can read but choose not to" (p. 1). Studies continue to show that 'performative pedagogy' where there is little opportunity for children to engage voluntarily with books, constrains their intellectual and affective engagement in reading (Hempel-Jorgensen et al, 2018). Yet the converse is also true when teachers create a reading culture in their classrooms where reading is associated with enjoyment. Free reading choice has been shown to encourage personal engagement, support the emergence of critical appreciation, seed literary behaviours, and improve literacy skills (Cliff-Hodges, 2010). Therefore, teachers who create inclusive learning opportunities for all may break the cycle of inequitable literacy practices and provide prolonged engagement with reading for every child, not just the 'fast finishers' (Vanden Dool \& Simpson, 2021).

Equitable programs where teachers make deliberative choices within socially situated and localised literacy practices have been shown to make a difference to disadvantaged students. For example, a large-scale design experiment study based on the Strathclyde Three Domains Tool reveals how educators enabled more inclusive literacy teaching by attending to the three intersecting domains of students' cultural and social capital, cognitive knowledge and skills, identity and agency (Ellis \& Rowe, 2020). Based on the results of this research, it is important for PST to be prepared to take up the challenge of enacting equity in practice by developing approaches to the teaching of reading that can engage diverse students. This is a challenge for initial teacher education (ITE) programs, as mandated literacy content limits the time available to give PST experience with reading, selecting and teaching with a wide range of children's literature (Simpson, 2016). Yet good teaching relies on high quality pedagogy that depends on the intellectual work of teachers who have developed capacity to make 
appropriate decisions for children's different needs. The development of pedagogic reasoning is seen as key to professional knowledge (Loughran, 2019). Therefore,

Equitable programs where teachers make deliberative choices within socially situated and localised literacy practices have been shown to make a difference to disadvantaged students educating PST through a dialogic approach that blends learning about children's literature while learning through children's literature is a strategic solution that deepens understanding as it enriches engagement. Exploration of paired reading autobiographies provides insight into how strategic learning design impacts on PST capacity to notice critical features in literacy landscapes of practice (Ellis et al.,

2020).

\subsection{Teacher knowledge of children's literature}

Research reveals the importance of teachers being good at teaching reading and also being committed readers (Commeyras et al., 2003). The value of reading for pleasure cuts across the issues of equity raised above as it offsets emphasis on reading skills and provides opportunities for all students to engage with quality texts (Cremin et al., 2014, p. 1). Yet, despite the impact that teachers' personal reading habits may have on children, it has been shown that many teachers do not have sufficient background knowledge about children's literature to inform their use of it in teaching (Cremin et al., 2008). Teachers' low engagement with children's literature is associated with weak professional confidence in working with literary texts in the classroom (Jenkinson, 2012). It is argued that, for teachers to have the capacity to match text to child, text to learning outcome, and text to discipline area, they need to regularly explore a wide variety of literary texts (Frey et al., 2008). This need is no less important for pre-service teachers who deserve to empower themselves to teach powerfully in their future classrooms through experiential learning with literary texts.

A comparative study of the teaching of children's literature in initial teacher education programs in four countries (Simpson, 2016) recorded the low number of hours dedicated explicitly to the topic. The findings revealed differing levels of PST confidence in their knowledge of children's literature ranging from low to high. More problematically, the findings also reported the resistance some PST had experienced during school placements to teaching with children's literature in place of reading scheme texts. Studies have shown that local school practices reduced the long-term influence of initial teacher education (Hong, 2010); this is a strong motivator to increase PST knowledge of children's literature in personally and professionally meaningful ways. This study proposes that if children's literature is employed as a catalyst for dialogic exchange in initial teacher education, it could prompt both intellectual and affective responses with long-lasting impact on future teaching behaviour. That 
is, through grounded experience, the ITE program could lead PST to reflect on content and pedagogic content knowledge as well as re-engage with the rarely read text form.

\subsection{Dialogic learning}

The rationale for the dialogic approach to teaching and learning demonstrated in this study is underpinned by a rich body of research demonstrating its benefit. The ground-breaking work

This study proposes that if children's literature is employed as a catalyst for dialogic exchange in initial teacher education, it could prompt both intellectual and affective responses with long-lasting impact on future teaching behaviour by Barnes (1976) in the 70's focused on the value of talk in the classroom. Talk is seen as creating an environment, where active learning is nurtured, not just as a mode for communication. Emerging initially from work on child language development in the field of linguistics (Halliday, 1975), a contextualised focus on the role of talk in education has been promoted since by scholars, including Alexander (2020) and Wegerif (2019), who place classroom discourse at the heart of pedagogic design. By approaching the topic from different theoretical directions, all these scholars have exemplified the social and cognitive benefits from encouraging exploration of knowledge through talk. Of particular relevance to this paper is the large Randomize Controlled Test (RCT) study of low Socioeconomic Status (SES) school children in the UK, which provides quantitative data reporting the significant impact of teachers' well designed talk practices on students' learning outcomes (Alexander, 2018).

Alexander (2020) proposes six dialogic principles to help teachers support student learning through interaction. These principles encourage equitable design for classroom talk that is collective, supportive, reciprocal, deliberative, cumulative and purposeful for all students. Research on dialogic teaching demonstrates how well-designed talk depends on the teacher's facility with a repertoire of discourse patterns (Alexander, 2018). A review of research on dialogic learning notes an emphasis on the role of the teacher in negotiating conditions for productive learning through talk (Jones \& Hammond, 2016). This responsibility provides a strong rationale for including dialogic engagement with children's literature as part of the curriculum as PST form their personal and professional identities as literate beings. Studies by Simpson (2016a, 2017, 2020) have investigated quality talk about quality texts in both higher education and primary school contexts and revealed the productive impact dialogic learning has on PST, school students and teachers.

The three fields of scholarship outlined above combine logically to influence the development of the research focus. The research question emerging from this literature asks: What is the impact of engagement with children's literature through dialogic interactions with children and literary texts on PST capacity to develop equitably informed literacy pedagogy? 


\section{Theoretical framework: viewing education as a complex, social system}

The study of ITE is informed by a social constructivist view of literacy that acknowledges the situated nature of literate practices (Street, 1995). This view positions initial teacher education as a specific context within which pre-service teachers are enculturated into ways of becoming teachers of reading. The interplay of macro, meso and micro forces such as policy, curriculum and personal experience will also inform the PST use of children's literature in their teaching (Simpson, 2016). The study adopts Freire's (1983) critical stance on exploring all pedagogic actions for evidence of deliberative equitable social impact. From this perspective, the work that PST do as they read and respond to literature is considered as individual 'aesthetic and intellectual pursuit' (Cliff-Hodges, 2010, p. 65), as well as professionally attuned, collaboratively engaged, cultural practice.

The ecological view of education explored by Ell et al. (2019) acknowledges the dynamic interplay of

By viewing education as a complex system of interrelated parts, my study uses a lens to zoom out to capture features of situated contexts and zoom in to capture details of intellectual deliberations. This exploration of effects brought about by a program that connects children and pre-service teachers across time and space to talk about children's literature is particularly suitable for a study investigating written and spoken texts. multiple influences operating in complex systems (Davis \& Sumara, 1997). In my undergraduate teaching context, education is read broadly as a complex system that encompasses school and higher education as well as policy and professional communities through which "initial teacher education intersects with the systems in which student learning is embedded" (Ell et al., 2019, p. 182). By viewing education as a complex system of interrelated parts, my study uses a lens to zoom out to capture features of situated contexts and zoom in to capture details of intellectual deliberations. This exploration of effects brought about by a program that connects children and pre-service teachers across time and space to talk about children's literature is particularly suitable for a study investigating written and spoken texts.

\section{Methodology: tracking the paths of interweaving data}

This paper reports holistically on an in-depth, qualitative analysis of an education program evolving over a semester, examining the causal links between components of learning and teaching. Hence the learning sequence designed for the PST is described as a set of iterative phases. It employs a mixedmethods, qualitative research design to capture rich data from a contextually situated case (Yin, 2014). Because the study has adopted the conceptual model of an ecological view of education systems (Ell et al., 2019), all data sets are viewed as interrelated. That is, learning emerges from complex systems, rather than being a product of a linear process. Therefore, the value of tracking multiple moving parts, 
static structures and hybrid interactions highlights the potential impact of making a small innovation in a large system.

\subsection{Participants: pre-service teachers from urban Australia}

The study is a bounded case of a study program offered at an urban Australian university. The fourthyear cohort of Bachelor of Education (Primary) PST was chosen through targeted convenience sampling (Cohen at al., 2018), given the researcher's access to the site. 200 primary school children aged 10-11 from eight local primary classes agreed to take part in the study. All participants joined voluntarily. Ethical procedures were followed to use data submitted with permission and then anonymised.

\subsection{Contextual background: embedding dialogic practices in learning about literature}

This section gives a brief overview of how triangulation of learning, teaching and assessment strategies supported my goal to develop equitable children's literature informed literacy pedagogy during a university semester.

Research shows that lack of teacher knowledge about literature prohibits broad approaches to the teaching of reading. In this study, to find out the knowledge of children's literature participant PST held, two data collection tools were embedded into the program. At the start of the semester, the Teachers as Readers survey (Cremin et al., 2008) was adapted for use in Australia with permission and run with the entire PST cohort (see Appendix 1). The data collection resulted in 76 completed surveys revealing PST existing reading habits and current children's book knowledge. Before classes commenced, the PST also wrote a retrospective reading autobiography (Farrar, 2020), providing insight to their personal experiences learning to read as young children (see Appendix 2).

The literature review discussed the benefits of embedding dialogic learning in the classroom. The learning design of the ITE program featured in this paper created dialogic spaces for PST to increase their interaction with children's literature as a deliberate focus to improve their knowledge of children's literature. To achieve this goal, I employed two strategically dialogic approaches. The first strategy, literature circles, depends on small groups of peers choosing, reading, and discussing the same book, taking on different discursive roles (Daniels, 1994). This part of the learning sequence contributed to the PST enriching their content knowledge of recently published Australian children's literature. It also deliberately scaffolded PST pedagogic awareness of the importance of productive dialogue in education settings. The PST read about literature circles and then organised their versions of them. In the lead-up to this part of the learning sequence, the PST matched theory to evidence by reading letters from children describing the impact that literature circles had on their critical reading. 
Consequently, the learning sequence positioned them both as reader participants and reflective practitioners.

The second dialogic strategy set up interactions between groups of PST, as they discussed letters received from a reading buddy program with primary children (aged 10-11 years old) from local schools. Each pre-service teacher was paired anonymously with two children. The school children wrote letters to the PST expressing their interest in reading, describing their favorite characters and naming some of their favorite authors / books. As the PST analysed the letters for structural and linguistic features and reading preferences, they engaged in multiple, iterative discussions with peers. This phase of the learning sequence contributed to PST developing pedagogic content knowledge on the topic of teaching writing. The dialogue also prompted the PST to develop deep knowledge of the use of children's literature in teaching. At the end of the semester, the PST wrote back to each child including recommendations of new books for the children to read. During the program, 400 letters were sent, 200 from children and 200 from PST.

The assessment tasks in the program increased critical awareness of teachers' decision making. To examine the development of PST emerging professional awareness, I focused on their pedagogic reasoning. At the end of the semester, PST were required to work in small groups and write rationales justifying what they would teach about by writing to the set of 8-10 children they had come to know through the buddy letter swap program. The PST explained learning outcomes based on an analysis of a set of children's letters and justified the books they would use as the basis of their teaching. In an appendix to their assessment submission, PST included the student letters they had annotated and the letters they wrote back to students, which provided the personalised book reviews.

To ensure that PST could individually justify their professional reasoning, all pre-service teachers met with their tutors for small group interviews in the final week of the semester. Each PST was expected to defend the planning of a lesson sequence according to core learning principles. The resulting dialogues prompted discussion of how aligning literary texts, children's interests and deliberately designed writing tasks equitably supports diverse learners. The PST were led to consider how strategic decisions about targeted learning design was evidence of their emerging professionalism.

At the end of the semester, after classes had finished, all PST wrote a second reading autobiography reflecting on the knowledge gained from reading and discussing the role of children's literature in the teaching of reading. 


\subsection{Data sources: following the impact of literature on learning}

Given the multi-layered nature of the learning design described above, six interwoven data collection methods were used during the study including: 1. A reading habit survey, 2. Personal reading autobiographies, 3. Letter exchanges, 4. Pedagogic rationales, 5. Small group interview and 6. End-ofsemester unit of study satisfaction survey (USS). For the purposes of this paper, the impact of PST learning with children's literature in ITE has been explored through one data source (paired reading autobiographies). The data selection before and after the unit of study affords depth of analysis and reveals changes in personal opinion, literary content knowledge and pedagogic content knowledge over time. Twenty-five viable pairs of reading autobiographies were collected, analysed and discussed below.

\subsection{Analysis: coding personal, pedagogic and professional indicators}

Influenced by the work of Ellis \& Rowe (2020, p. 421), the analytic codes chosen for this study align with the three domains of The Strathclyde Model. The indicators are used to code pre-service teachers' Personal Literary Engagement (cultural and social capital), Pedagogic Reasoning (cognitive knowledge and skills) and Emerging Professionalism (identity and agency) (see Figure 1). As the ITE in which the PST are enrolled expects them to develop an integrated professional, ethical and personal identity, this analytic frame is reasonable. The Three Domains Model (2020) was originally proposed to help pre-service teachers equitably support school students' learning in under-privileged contexts. In this paper, the model is adopted as an analytic framework to examine whether the strategic learning design of teaching with children's literature impacted as planned on the pre-service teachers' metaawareness of their own literacy teaching practices.

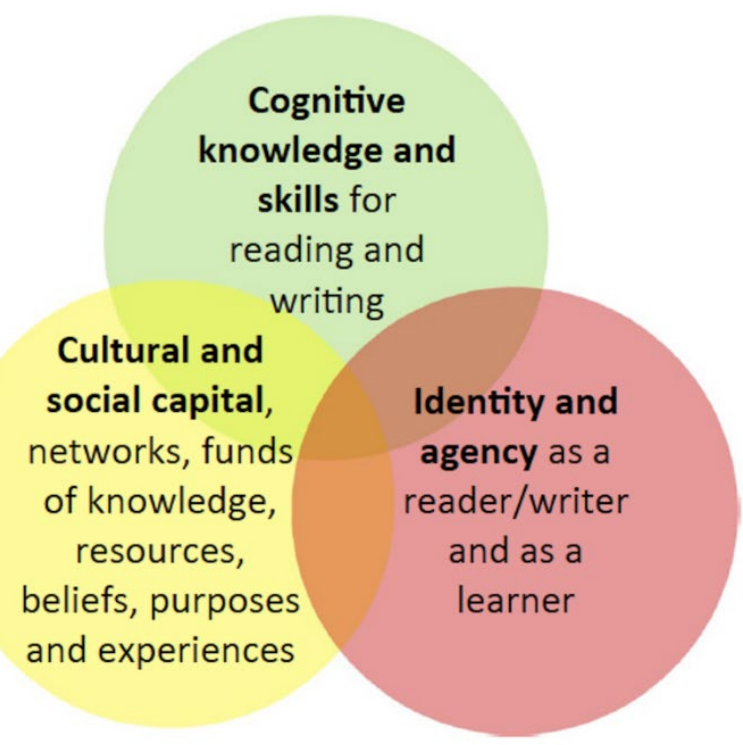

Figure 1: The Strathclyde Three Domain Tool for literacy teaching and assessment 
Thematic analysis of data collected from the paired reading autobiographies was undertaken. Brief analytic examples are provided in Table 1 to show how the coding relied on semantic content and other discursive language features identifiable using educational linguistics (Jones \& Hammond, 2016). Later, the findings indicate whether the PST reported positive (+ve) or negative (ve) experiences.

\begin{tabular}{|c|c|}
\hline Code name with definition & Example from PST \\
\hline $\begin{array}{l}\text { Personal Literary Engagement [PLE] indicators of } \\
\text { personal literary engagement [both +ve and -ve] were } \\
\text { selected on the basis of linguistic markers related to: } \\
\text { experience as a child, or as an adult external to } \\
\text { university study. These responses were typically } \\
\text { expressed in first person, non-theoretical / affective } \\
\text { language. }\end{array}$ & $\begin{array}{l}\text { "I remember having to take home-readers } \\
\text { home with me... I preferred to sit and read a } \\
\text { book... Books were my escape from the } \\
\text { bullying I was experiencing." }\end{array}$ \\
\hline $\begin{array}{l}\text { Pedagogic Reasoning }[\mathrm{PR}] \text { indicators of pedagogic } \\
\text { reasoning were selected on the basis of linguistic } \\
\text { markers related to: content knowledge and pedagogic } \\
\text { content knowledge regarding the teaching of reading } \\
\text { or writing. These responses were typically expressed } \\
\text { in pragmatic outcome related / curriculum-based } \\
\text { terminology. }\end{array}$ & $\begin{array}{l}\text { "I remember doing a few activities with basic } \\
\text { sight words and rhyming during the earlier } \\
\text { years but do not remember how this was } \\
\text { further consolidated to reading fluently." }\end{array}$ \\
\hline $\begin{array}{l}\text { Emerging Professionalism [EP] indicators of } \\
\text { emerging professionalism were selected on the basis } \\
\text { of linguistic markers related to: professional } \\
\text { forecasting and / or critical commentary on literacy } \\
\text { practices. These responses were rarer than the } \\
\text { others, and typically expressed as future focussed or } \\
\text { theory informed reflections revealing nascent teacher } \\
\text { identity and occasionally awareness of teacher } \\
\text { agency. }\end{array}$ & $\begin{array}{l}\text { "I think reading is a skill that a lot of students } \\
\text { can take for granted and using quality } \\
\text { literature can open so many doors for } \\
\text { students who struggle to engage in the } \\
\text { 'process'." }\end{array}$ \\
\hline
\end{tabular}

Table 1. Coded examples 


\section{Findings: patterns of interaction with children's literature from childhood to higher education}

A total of seventeen items were identified by analysing the twenty-five initial autobiographies as notable factors in reading experiences. Items were counted as notable if $10 \%$ or more of the individuals mentioned them in their reflections. The factors were classified according to the three categories of Personal Literary Engagement (seven factors), Pedagogic Reasoning (three factors) and Emerging Professionalism (one factor) depending on vocabulary and

It is heartening to note that $84 \%$ of the ITE cohort report enjoying reading as adults, but the reading autobiographies reveal mixed experiences on the pathway to their final year of other linguistic markers. The tables below provide a breakdown of the scoring system according to factor grouping, instance and positive or negative weighting. It is heartening to note that $84 \%$ of the ITE cohort report enjoying reading as adults, but the reading autobiographies reveal mixed experiences on the pathway to their final year of ITE.

\subsection{Personal Literary Engagement categories of evidence}

\begin{tabular}{|l|r|r|r|r|}
\hline Home Personal Literary Engagement & \% mentions & +ve & -ve & no mention \\
\hline enjoyed as a child & $76 \%$ & 19 & 4 & 2 \\
\hline books in home & $72 \%$ & 18 & 4 & 3 \\
\hline read to by others & $64 \%$ & 16 & 6 & 3 \\
\hline public library use & $56 \%$ & 14 & 3 & 8 \\
\hline reading for pleasure & $48 \%$ & 12 & & 13 \\
\hline reading to others & $40 \%$ & 10 & & 15 \\
\hline school readers at home & $16 \%$ & 4 & 2 & 19 \\
\hline
\end{tabular}

Table 2. Personal Literary Engagement with reading at home positive and negative influences

In Table 2, the autobiography data demonstrates that the home environment stimulated a relatively positive reading experience for most PST. Five out of seven factors related to personal literacy engagement through reading at home, including being read to, books in the home and visits to local libraries, were mentioned positively in at least $50 \%$ of the reflections. It should be noted that books in the home was one factor where PST with EALD (English as an Additional Language or Dialect) backgrounds had a marked experience as children compared to peers whose first language was English. The autobiographies written by PST 1, 2, and 3 who all had EALD backgrounds, recorded less access to books at home in their first language or in English. These PST developed different linguistic and cultural capital from their peers, which shaped their reading identities accordingly. 
PST 1: During my early primary years, I wasn't usually read bedtime stories, however I would often read assigned literacy books to my parents as part of homework and practice. I also remember doing literacy reading cards, which I didn't particularly enjoy.

One factor, the experience of taking school readers home to read, was rated more positively than negatively but only featured in $16 \%$ of mentions. This factor shows reading practices crossing the boundary between home and school contexts. Its lack of importance to the PST could indicate how young readers can differentiate between reading practices. For, even though only $48 \%$ of the PST made positive commentary about reading for pleasure as young children, this finding accords with the research that reading for pleasure is a key motivator (Cremin, 2014a), whereas reading for skills practice can work against reading engagement (Mullis et al., 2009).

\begin{tabular}{|l|l|l|l|l|}
\hline $\begin{array}{c}\text { School Personal } \\
\text { Literary Engagement }\end{array}$ & $\begin{array}{c}\text { \% } \\
\text { mentions }\end{array}$ & +ve & -ve & no mention \\
\hline teacher scaffolding & $60 \%$ & 15 & 2 & 8 \\
\hline whole group & $52 \%$ & 13 & 1 & 11 \\
\hline as work & $52 \%$ & & 13 & 12 \\
\hline school library use & $44 \%$ & 11 & & 14 \\
\hline individual reading & $28 \%$ & 7 & 5 & 13 \\
\hline
\end{tabular}

Table 3. Personal Literary Engagement with reading at school positive and negative influences

In Table 3, the autobiography data shows that PST had varied experiences of learning to read at school. Two out of five factors related to personal literacy engagement were mentioned positively in at least $50 \%$ of the reflections. These factors were teacher scaffolding and whole group reading. School library use was mentioned positively in $44 \%$ of the reflections. In contrast, reading as work was negatively commented in $52 \%$ of the reflections.

PST 2: ... being an EAL/D student who moved to Australia when I was 9, I do not remember having a library with a vast variety of books which interested me at school.

PST 3: Reading wasn't something that I found myself turning towards. I never usually read at school.

As access to a wide range of books has been upheld as a major impact on reading behaviour (Jerrim \& Moss, 2019), it is pleasing to see that library use outside of school was remembered as being an important factor in many PST's personal reading histories with positive commentary from $56 \%$ of the cohort. However, despite the promising results that can be achieved through student engagement with libraries in schools, it is a concern that $56 \%$ of PST did not refer to school libraries at all. There is 
clearly work to be done to remind PST of the potential of teachers and librarians working together (Cremin, Mottram, Collins, Powell, \& Safford, 2009).

\subsection{Pedagogic Reasoning categories of evidence}

\begin{tabular}{|c|c|c|c|c|}
\hline $\begin{array}{c}\text { Pedagogic } \\
\text { Reasoning }\end{array}$ & $\begin{array}{c}\text { \% } \\
\text { mentions }\end{array}$ & +ve & -ve & no mention \\
\hline $\begin{array}{c}\text { Productive } \\
\text { strategies }\end{array}$ & $84 \%$ & 21 & 4 & \\
\hline $\begin{array}{c}\text { Unproductive } \\
\text { strategies }\end{array}$ & $32 \%$ & 8 & 17 & \\
\hline Empathy & $16 \%$ & 4 & & 21 \\
\hline
\end{tabular}

Table 4. Pedagogic Reasoning from reflecting on reading as a child

The first autobiography was not deliberately intended to stimulate the PST to reflect on themselves as teachers. It was fascinating, therefore, to note the language of literacy education inflected their reflections on themselves as young readers. Table 4 shows a high proportion of mentions ( $84 \%$ of cohort) and reveals PST familiarity with the language of the profession through comments on the positive pedagogic strategies they experienced as children. In addition, 32\% of PST recorded unproductive pedagogic strategies experienced at school. The vocabulary chosen to exemplify their perceptions named reading programs, curriculum planning, classroom management, syllabus content and other identifiable evidence of the content and pedagogic knowledge they had already established before the semester started.

PST 4: I remember doing a few activities with basic sight words and rhyming during the earlier years, but do not remember how this was further consolidated to reading fluently.

As data was collected in the final year of the PST's undergraduate degree, knowledge of literacy pedagogy was expected. However, the level of critical awareness confirmed that these young teachers were also developing pedagogic insight, which would inform their future decision making. This outcome aligns with the goal of the final unit to expand on existing content knowledge, enhance understanding of reading for pleasure, and encourage professional responsiveness to deliberative planning. That is, the PST were challenged through research, readings and the letter exchange program to notice individual children's literacy needs and design teaching practices informed by syllabus and adapted to local contexts (Simpson, 2020). 


\subsection{Emerging Professionalism category of evidence}

\begin{tabular}{|c|l|l|l|l|}
\hline $\begin{array}{c}\text { Emerging } \\
\text { Professionalism }\end{array}$ & $\begin{array}{c}\text { \% } \\
\text { mentions }\end{array}$ & +ve & -ve & no mention \\
\hline Intentionality & $36 \%$ & 9 & & 16 \\
\hline
\end{tabular}

Table 5. Emerging Professionalism from reflecting on reading as a child

At the beginning of the semester, it was interesting to see that some PST were already forecasting their influence on future students and considering the lessons they could draw purposefully from their past experience as readers. Just over a third of PST provided evidence of Emerging Professionalism. However, as the task did not overtly seek this kind of commentary, the fact that a third of PST were able to express this awareness without prompting is taken to be a strong indication of their ITE grounding to this date.

PST 5: I have developed a genuine passion for children's literature and [will] endeavour to build a functioning library in my own classroom.

One important point from the findings was a suggested relationship between positive experience as a child reader and predilection to develop professional intentionality prior to the focus unit of study.

That is, the PST who had grown up with positive affirmations of themselves as readers through Personal Literary Engagement were already more able to discern and explain pedagogic
From the sample of data collected at the beginning of the semester, it is possible to see a trend that relates strong early reader identity with greater teacher insight at the commencement of semester. That is, the PST who had grown up with positive affirmations of themselves as readers through Personal Literary Engagement were already more able to discern and explain pedagogic strategies and frame up their future teacher agency than peers who recounted a weaker reader identity. As shown above, PST 1, 2 and 3 all had negative reading experiences at home and school, and all reflected negatively on Pedagogic Reasoning in the first reading autobiography. As a result of this trend, it was decided that a strong indicator for the impact of the unit would be a shift by these PST from the low initial insight of Pedagogic Reasoning and no Emerging Professionalism, to greater capacity in both.

Figure 2 uses colour shading to indicate reading experience and pedagogic rationale data from reading autobiography 1 with negative, positive and n/a weighting. Each column represents one PST. Asterisks in nine columns indicate the PST who demonstrated Emerging Professionalism prior to the semester. The pattern read from left to right shows a clear trend that PST with positive reading identity were more likely to express professional insights. 


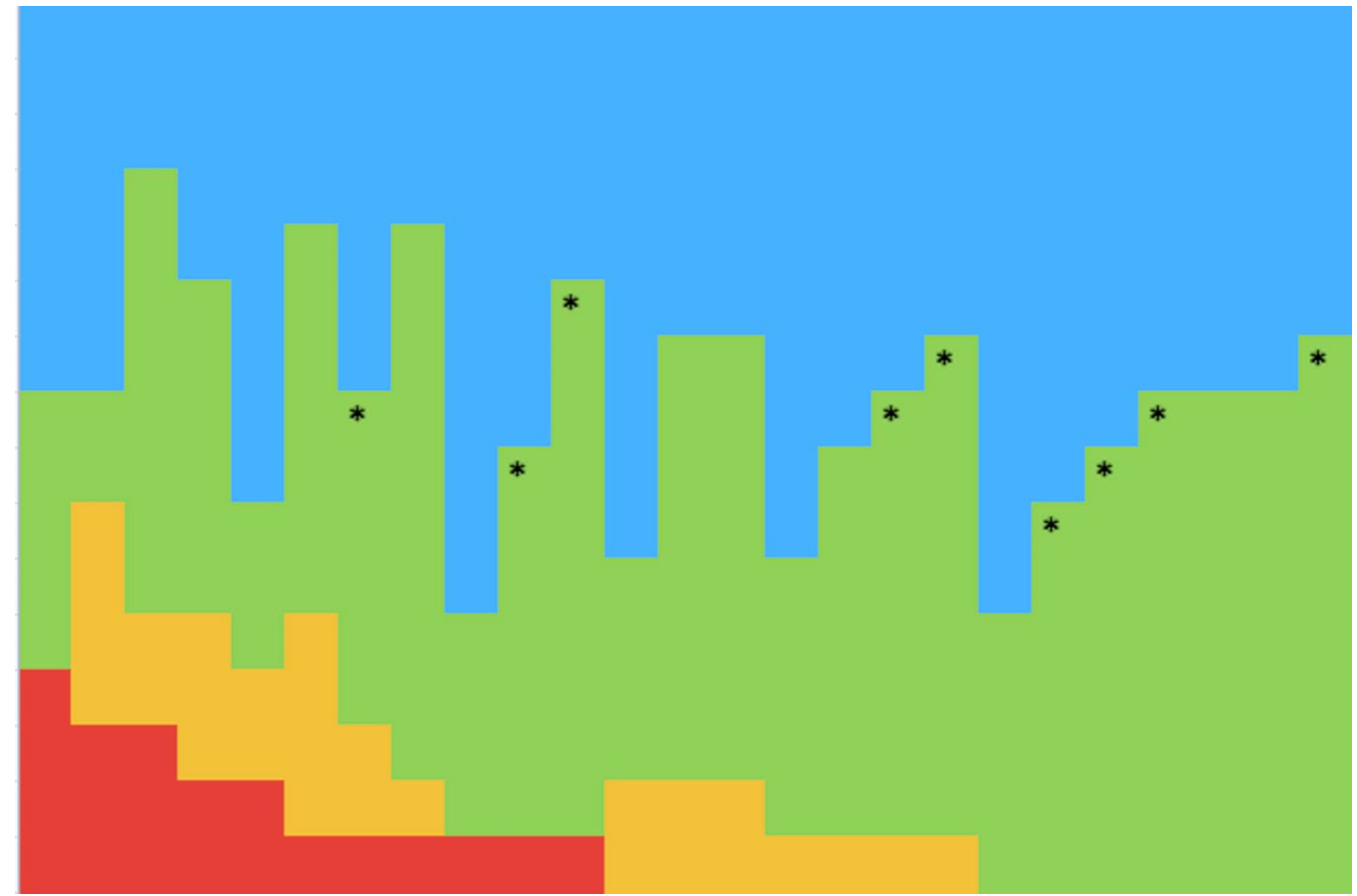

Figure 2: Trends linking experience as child reader to professional insight prior to semester

\subsection{Reading autobiography 2 post semester}

A total of eight themes were identified in Autobiography 2 (hereafter A2) as notable and responses were coded as Personal Literary Engagement (two factors), Pedagogic Reasoning (four factors) and Emerging Professionalism (two factors). Themes were counted as notable if $10 \%$ or more of the PST mentioned them in their reflections. However, as most mentions of all three types were present in different combinations for all themes, factors are represented in the tables according to groupings of greatest emphasis across the whole cohort. That is, the evidence has been presented to show relative weighting within factor grouping.

\subsection{Personal Literary Engagement emphasis of evidence}

\begin{tabular}{|c|l|l|l|l|l|}
\hline & $\begin{array}{c}\text { Personal } \\
\text { Literary } \\
\text { Engagement }\end{array}$ & $\begin{array}{c}\text { Pedagogic } \\
\text { Reasoning }\end{array}$ & $\begin{array}{c}\text { Emerging } \\
\text { Professionalism }\end{array}$ & no mention & Total \% \\
\hline Teacher who reads & $76 \%$ & $12 \%$ & $0 \%$ & $12 \%$ & $100 \%$ \\
\hline Adult experience & $16 \%$ & $56 \%$ & $28 \%$ & $100 \%$ \\
\hline
\end{tabular}

Table 6. Personal Literacy Engagement with reading as a teacher

In the A2 prompts, there was a far lower emphasis on Personal Literacy Engagement than in Autobiography 1 (hereafter A1). The intent was for PST to reflect on the development of their 
professional learning at the end of their last unit of English study. However, the question asking them to report on their identities as teachers who read surprisingly led most of the cohort (76\%) to form their responses as a personal focus. Only $12 \%$ of PST provided pedagogic reasoning in their responses showing that the PST perceive teacher reading habits are a matter of personal responsibility.

PST 1: I realised that being able to find the joy and value in reading children's literature has made me find the value in sharing this joy and value with students.

\subsection{Pedagogic Reasoning emphasis of evidence}

\begin{tabular}{|c|c|c|c|c|c|}
\hline & $\begin{array}{c}\text { Personal } \\
\text { Literary } \\
\text { Engagement }\end{array}$ & $\begin{array}{l}\text { Pedagogic } \\
\text { Reasoning }\end{array}$ & $\begin{array}{c}\text { Emerging } \\
\text { Professionalism }\end{array}$ & no mention & Total \% \\
\hline Reader who teaches & $4 \%$ & $88 \%$ & 0 & $8 \%$ & $100 \%$ \\
\hline $\begin{array}{c}\text { Experience on } \\
\text { placement }\end{array}$ & 0 & $\begin{array}{l}68 \%+\text { ve } \\
12 \% \text {-ve }\end{array}$ & $4 \%$ & $16 \%$ & $100 \%$ \\
\hline $\begin{array}{l}\text { School use of } \\
\text { Reading for } \\
\text { Pleasure }\end{array}$ & 0 & $\begin{array}{l}48 \%+\text { ve } \\
16 \% \text {-ve }\end{array}$ & 0 & $36 \%$ & $100 \%$ \\
\hline University learning & $4 \%$ & $80 \%$ & $16 \%$ & 0 & $100 \%$ \\
\hline
\end{tabular}

Table 7. Pedagogic Reasoning from reflecting on teaching reading

Reflection on the teaching of reading demonstrated PST had developed stronger Pedagogic Reasoning, as should be expected. This was particularly noticeable where PST commented on factors that influenced them positively. The low weighting for Personal Literary Engagement in this set of factors stands in contrast to the factor of teachers as readers above. In the data of Table 7, PST comments reveal their association of being readers who teach as a matter of professional responsibility. This result could stem from a lack of familiarity with the concepts, which were only introduced in the current semester. The findings echo Cremin et al.'s study that shows it is important for teachers to be both Teachers as Readers and Reading Teachers (2014). By the final year of their degree these PST have had many practicum experiences. Therefore, the positive findings for PST developing pedagogic reasoning in this unit of study speaks against Hong's 2010 proposition that university learning loses its power when contrasted with lived classroom experience.

PST 2: Having to read a text and thoroughly engage with it in literature circles allowed me to take on the role of a 'teacher who reads and a reader who teaches', and practice it with my peers.

The two other factors heavily weighted for pedagogic reasoning show both positive and negative influences on PST. Experience on placement was ranked by $68 \%$ of PST as a positive contribution to 
their learning. This figure contrasts with $12 \%$ of PST who gave negative commentary. The other factor with positive (48\%) and negative (16\%) ranking was reading for pleasure, which provided insight into various PST perspectives. It is possible that a weighting of $36 \%$ of $n /$ a reflects the lack of time allocated for reading for pleasure in schools. This interpretation may be viable given the inequitable emphasis on skills in reading programs provided for struggling readers (Hempel-Jorgensen et al., 2018).

\subsection{Emerging Professionalism emphasis of evidence}

\begin{tabular}{|c|l|l|l|l|l|}
\hline & $\begin{array}{c}\text { Personal } \\
\text { Literary } \\
\text { Engagement }\end{array}$ & $\begin{array}{c}\text { Pedagogic } \\
\text { Reasoning }\end{array}$ & $\begin{array}{c}\text { Emerging } \\
\text { Professionalism }\end{array}$ & no mention & Total \% \\
\hline Intentionality & $12 \%$ & $52 \%$ & $36 \%$ & & $100 \%$ \\
\hline Confidence & $8 \%$ & $36 \%$ & $36 \%$ & $20 \%$ & $100 \%$ \\
\hline
\end{tabular}

Table 8. Emerging Professionalism from reflecting on teaching reading

Reflections that demonstrated emerging professionalism were coded if they were examples of teaching as intellectual work (Loughran, 2019). 36\% of PST demonstrated this awareness equally in their responses about confidence in teaching and intentionality. It should be noted that unlike $A 1$, where evidence of Emerging Professionalism only existed in one item, in A2 there were Emerging Professionalism comments in all themes. In contrast to A1, 17 PST demonstrated Emerging Professionalism at the end of the semester. This indicates that the course design provoked increased emergence of professionalism over the semester. However, more data needs to be collected to judge whether the impact is consistent across cohorts. Although there was an increase from A1 to A2 in evidence of Emerging Professionalism, more PST couched their comments in terms of Pedagogic Reasoning. As shown in Simpson (2016), this may indicate that Pedagogic Reasoning is the main focus at this stage in their career.

It is encouraging to see that those PST who were already demonstrating Emerging Professionalism in A1 were consistent. However, far more encouraging is the finding that PST 1, 2 and 3 identified in A1 as holding weak reader identity changed their attitudes by the end of the semester. In A2, all three of these PST expressed strong Pedagogic Reasoning and Emerging Professionalism in their reflections on the teaching of reading with children's literature. This finding supports the positive impact of the unit on improving PST confidence teaching with children's literature (Jenkinson, 2012).

PST 3: I need to enrich my knowledge and experience of literature to ensure successful learning opportunities. However, this year has influenced my ability to develop this goal by being critical of the way reading experiences are shaped in schools and the different ways that literature can be used skillfully in classroom practice. 


\section{Discussions}

\subsection{Zooming-in to see individual change}

What is the impact on PST engagement with children's literature through dialogic interactions with children and literary texts on PST capacity to develop equitably informed literacy pedagogy? To address this research question, I provided evidence of changes in personally, pragmatically and critically informed pedagogic awareness. In the discussion below, I present two interrelated propositions. First, if the fiction effect (Jerrim \& Moss, 2019) exists, the PST should have shown increased interest in reading children's literature by the end of the semester. Second, if dialogic pedagogies do support development in critical understanding through social interaction (Alexander, 2020), the PST should have become more alert to their professional responsibility as future teachers to make deliberative decisions. That is, they would be recognising the importance of designing reading programs that ensured all children, regardless of their ability, would be given regular access to and extended time with children's literature.

The zoomed-in view of data from the reading autobiographies reveals that the unit helped all PST enrich personal literacy engagement during the semester. Not only did they take opportunities to reengage with reading books, but they also became more informed about the principles of Reading for Pleasure and the importance of deliberative learning design. This positive outcome can be found in Personal Literary Engagement coded comments, such as: "My recent love for reading has been ignited through this unit", and Pedagogic Reasoning coded comments "Having to read a text and thoroughly engage with it in literature circles allowed me to take on the role of a 'teacher who reads and a reader who teaches', and practice it with my peers." The PST were aware that their learning had been framed strategically and were able to make meta-commentary on the unit as an educative experience. "This course has helped me reach out to children's books with a purpose which allowed me to enjoy the perks of reading again."

The letters to buddies also show the productive impact of PST learning with children's literature as it increased their knowledge of children's literature. The reading autobiographies do not list the specific titles that PST searched for to match children's reading interests, demonstrating the ability to build reading communities (Cremin et al., 2009; Frey et al., 2008). However, the second reading autobiographies show that the PST who had positive reading childhood experiences and those who had negative experiences were strongly committed to enhancing skills-based literacy pedagogy through children's literature by the end of the semester. PST comments, such as "The challenge is to ensure that students still enjoy reading and don't see it as merely an academic obligation or task", 
signal how they are alert to the risks of limiting children's access to literary texts by teaching them to read through a constrained skills approach (Cliff-Hodges, 2010).

The personal engagement aspect was a pleasing result. However, in relation to point two, there are indicators of impact showing that these young teachers will amend their approach to teaching in the future. There was clear evidence of increased capacity in pedagogic reasoning and emerging professionalism over the course of the semester, as the PST strengthened the foundations of their professional knowledge (Loughran, 2019) on teaching with children's literature. Even though some PST had steeper learning curves than others, all achieved positive outcomes. For instance, the trend identified in Autobiography 1 for PST with a poor reader identity to be associated with weaker insight into productive pedagogies was equalised. The findings above acknowledge the socially situated context of learning (Street, 1995). They show how PST 1, 2 and 3 whose negative experiences with reading in childhood were captured in $\mathrm{A} 1$, developed skills at explaining deliberative pedagogic rationales in their post semester reflections. These three PST demonstrated the emergence of purposeful intent to enact professional agency in the future to work towards improving social equity in their classrooms (Freire, 1983). By reflecting on their own reading autobiographies, their interaction with literature in the university program and their observation of reading in schools, each student formed new meta-awareness of their identities as reading teachers and teachers of reading.

I argue that these changes were influenced by iterative, dialogic processes, which engaged these PST in productive talk about children's literature during the semester. Combined with the power of children's literature to mindfully disrupt entrenched literacy practices that shaped the reading experiences of young primary school children, the dialogic approach stimulated new thought processes for the PST. The paired quotes show the value of working iteratively with children's literature. The impact shifted PST attention from personalised negative perceptions of home or school reading practices towards pedagogic awareness of the I argue that these changes were influenced by iterative, dialogic processes, which engaged these PST in productive talk about children's literature during the semester. Combined with the power of children's literature to mindfully disrupt entrenched literacy practices that shaped the reading experiences of young primary school children, the dialogic approach stimulated new thought processes for the PST importance for teachers to read quality literature. This result echoes the studies by Commeyras (2003), Cremin (2014), Simpson (2020) and others that demonstrate rich engagement with children's literature can support teachers to develop personal and professional understanding. 
Overall, the data from the reading autobiographies demonstrates how the PST worked through concepts about the teaching of reading connected to their cultural and social capital, their cognitive knowledge and skills, and their professional identity and agency (Ellis \& Rowe, 2020). The three approaches interacted in a way beneficial to the development of pedagogic content knowledge (Shulman, 2015). Isolated as stand-alone elements the same impact would not have occurred. As Simpson, Cremin \& Smith in a forthcoming paper propose, aesthetic appreciation of literature, personal engagement with literature, and pedagogic sensitivity to literature are insufficient in and of themselves. It is teachers' capacity to work across all elements of the 'additive trio' that will encourage them to take agentic action on behalf of learners and inform equitable practices.

\subsection{Zooming-out to appreciate systematic design}

The theoretical framework adopted for the study argues for attention to be paid to the complexity of education systems (Davis \& Sumara, 1997). Therefore, it is important to consider both the learning design adopted for the unit and the socio-cultural context in which it was implemented. Taking a zoomed-out perspective of the situated learning encourages a holistic appreciation of the connectedness made possible within this particular education ecology for this group of PST. The letter exchange example shows how ideas can 'travel' and new practice can emerge when an idea meets the right conditions (Ell et al., 2019, p. 21). Iterative and dialogic pathways of interaction around teacher knowledge and practice were established for PST with schools from the start of the semester. Authentic communication with school children was realised in the form of letters, which prompted extended discussions on student learning. Parents and teachers permitted the letter exchange as the project aligned with the priorities and practices of schools and communities. The partnership between the university and the schools may be a manifestation of state and national education system policy, but the benefit to learners was up close and personal.

The unit exhibited dialogic principles because the interactive nature of the pedagogic innovation created multiple opportunities for social and intellectual engagement over time (Alexander, 2020). The deliberative design to create dialogic spaces for interactions spanning peer to peer/ child to PST/ and PST with tutor ensured that dialogue was purposefully embedded in all weeks and learning and assessment tasks within the unit. Some instances of talk were designed to support learning, e.g. general tutorial discussions; others contributed more visibly to formative assessment, e.g. the peer feedback given during literature circles; and others, for example the pedagogic rationale interviews, were explicitly used for formal summative assessment. The power of this kind of learning when run collaboratively with learners as partners can be described by referring to Alexander's principles as seen in the following overview of the letter exchange program. 
There is clear evidence of cumulative benefit to the PST and school children of quality talk about quality texts, as facts and opinions about reading were woven into "coherent lines of thinking and enquiry" (Alexander \& Wolfe, 2008, p. 8). The letter exchange component of the ITE program is an excellent example where purposeful dialogue sets up well-planned interactions between PST, addressing clear learning goals. The incorporation of letters from children about literary texts prompted PST to think responsively about complex pedagogy. It could be argued that the school children and pre-service teachers developed reciprocal relationships as they shared ideas and proposed new viewpoints. Admittedly some of this communication was in writing and on a small scale, given that PST worked in pairs and small groups. However, the response letter to the children not only closed the loop via a social contact, but also shared important knowledge up and down the chain through PST, academic, school teacher and child. Therefore, it can be argued that the interaction of collaborative dialogue, engaged reading and targeted writing scaffolded PST's aesthetic responses to and content knowledge of children's literature in a cumulative and responsive fashion (Alexander, 2020).

\section{Conclusion}

In my teaching, I have deliberately embedded discursive exploration of children's literature to foster professional dialogue. I have reframed the role of talk about books and meta-talk about 'talk for learning' as a core part of this undergraduate unit. In this way, the 'fiction effect' potential to improve student engagement with reading (Jerrim \& Moss, 2019) is fostered for my current PST and their future pupils. A broad approach to understanding the social and intellectual demands of reading has been supported through dialogue to help the PST

- attend to reader identity (their own and their letter buddies),

- consider the importance of multiple components necessary to help students become engaged readers, and

- practice the intellectual work of teachers who choose to provide equitable access to literacy. Working to improve children's will to read (Graves, 2002), I am helping the PST avoid the trap of applying a one-size-fits-all mentality that simplifies the complexity of teaching. Acknowledging that teachers face many challenges that may constrain their professional practice, this study of PST was designed to support deliberative intellectual work. As the unit is aligned with the program goal, which expects PST to develop an integrated professional, ethical and personal identity, the outcomes of this research prove that the approach taken contributes to the achievement of this goal. 


\section{References}

Alexander, R. (2018). Developing dialogic teaching: genesis, process, trial. Research Papers in Education, 33(5), 561-598.

Alexander, R. (2020). A dialogic teaching companion. Routledge.

Alexander, R., \& Wolfe, S. (2008). Argumentation and dialogic teaching: Alternative pedagogies for a changing world. Futurelab.

Barnes, D. (1976). From communication to curriculum. Penguin.

Cliff-Hodges, G. (2010). Reasons for reading: Why literature matters. Literacy, 44(2), 60-68.

Cohen, L., Manion, L., \& Morrison, K. (2018). Research methods in education (8th ed.). Routledge.

Commeyras, M., Bisplinghoff, B.S. \& Olson, J. (2003). Teachers as Readers: perspectives on the importance of reading in teachers' classrooms and lives. International Reading Association.

Cremin, T. (2014). The UKLA projects: Teachers as readers and building communities of readers. In T. Cremin, M. Mottram, F. M. Collins, S. Powell \& K. Safford (Eds.), Building communities of engaged readers: Reading for pleasure (pp. 89-107). Routledge.

Cremin, T. (2014a). Reading for pleasure and reader engagement: Reviewing the research. In T. Cremin, M. Mottram, F. M. Collins, S. Powell \& K. Safford (Eds.), Building communities of engaged readers: Reading for pleasure (pp. 5-19). Routledge.

Cremin, T., Mottram, M., Collins, F. Powell, S. \& Safford, K. (2009). Teachers as readers: Building communities of readers. Literacy, 43(1), 11-19.

Cremin, T., Mottram, M., Bearne, E., \& Goodwin, P. (2008). Exploring teachers' knowledge of children's literature. Cambridge Journal of Education, 38(4), 449-464.

Daniels, H. (1994). Literature circles: Voice and choice in the student centred classroom, Stenhouse Publishers.

Davis, B., \& Sumara, D. (1997). Cognition, complexity and teacher education. Harvard Educational Review, 67(1), 105-127.

ElI, F., Simpson, A., Mayer, D., McLean Davis, L., Clinton, J. \& Dawson, G (2019). Conceptualising the impact of initial teacher education. Australian Educational Researcher, 46(1), 177-200.

Ellis, S., \& Smith, V. (2017). Assessment, teacher education and the emergence of professional expertise. Literacy, 51(2), 84-93.

Ellis, S., \& Rowe, A. (2020). Literacy, social justice and inclusion: A large-scale design experiment to narrow the attainment gap linked to poverty. Support for Learning, 35(4), 418-439.

Farrar, J. (2020, November 20). "I prefer to read books at my level”: An enquiry into student teachers' perspectives of children's literature." [Connecting Literature and Literacy.] Fostering Dialogue: Teaching Children's Literature at University, University of Padua, Italy. https://www.childrensliterature-unipd.it/

Freire, P. (1983). The importance of the act of reading. The Journal of Education, 165(1), 5-11.

Frey, N., Fisher, D., \& Berkin, A. (2008). Good habits, great readers: Building the literacy community. Allyn \& Bacon.

Graves, D. (2002). Testing is not teaching: What should count in education. Heinemann.

Halliday, M.A.K. (1975), Learning how to mean. Edward Arnold.

Hempel-Jorgensen, A., Cremin, T., Harris D. \& Chamberlain, L. (2018). Pedagogy for reading for pleasure in low socio-economic primary schools: beyond 'pedagogy of poverty'? Literacy, 52(2), 86-94. 
Hong, J. (2010). Pre-service and beginning teachers' professional identity and its relation to dropping out of the profession. Teaching and Teacher Education, 26, 1530-1543.

Jenkinson, A. (2012). A second golden age of Canadian children's literature. Booknews, 5(3) 4-5.

Jerrim, J. \& Moss, G. (2019). The link between fiction and teenagers' reading skills: International evidence from the OECD PISA study. British Educational Research Journal, 45(1), 181-200.

Jones, P. \& Hammond, J. (2016). Talking to learn: Dialogic teaching in conversation with educational linguistics. Research Papers in Education, 31(1), 1-4.

Loughran, J. (2019). Pedagogical reasoning: The foundation of the professional knowledge of teaching. Teachers and Teaching, 25(5), 523-535.

Mullis, I., Martin, M., Kennedy, A., Trong, K. \& Sainsbury, M. (2009). PIRLS 2011 Assessment framework. International Association for the Evaluation of Educational Achievement. TIMSS and PIRLS International Study Center.

Shulman, L. S. (2015). PCK: Its genesis and exodus. In A. Berry, P. Friedrichsen \& J. Loughran (Eds.), Reexamining pedagogical content knowledge in science education (pp. 3-13). Routledge.

Simpson, A. (2020). Developing noticing capacity to support teacher professionalism through dialogic learning with literary texts. In A. Simpson, F. Pomerantz, D. Kaufman, \& S. Ellis (Eds.). Developing habits of noticing in literacy and language classrooms: Research and practice across professional cultures. (pp. 134-153). Routledge.

Simpson, A. (2017). Teachers negotiating professional agency through literature based assessment. Literacy Special Issue. 51(2) 111-119.

Simpson, A. (2016). The use of children's literature in teaching: A study of politics and professionalism within teacher education. Routledge.

Simpson, A. (2016a). Dialogic teaching in the initial teacher education classroom. Invited paper for Special Issue: Talking to Learn: Dialogic Teaching in conversation with educational linguistics, Research Papers In Education, 31(1) 89-106.

Street, Brian V. (1995). Social literacies: Critical approaches to literary development. Pearson Education Asia.

Thomson, S., Hillman, K., Schmid, M., Rodrigues, S., \& Fullarton J. (2016). Reporting Australia's results: PIRLS 2016. Retrieved from the ACER Search website: https://research.acer.edu.au/pirls/1/

Vanden Dool, C. \& Simpson, A. (2021). Reading for pleasure: Exploring reading culture in an Australian early years classroom, Literacy. n. pag. Web.

Wegerif, R. (2019). Dialogic education. Oxford research encyclopedia of education. Oxford University Press.

Yin, R. K. (2014). Case study research: Design and methods (5th ed.). Sage.

How to cite this paper:

Simpson, A. (2021). Teaching with Children's Literature in Initial Teacher Education: Developing Equitable Literacy Pedagogy through Talk about Books. Journal of Literary Education, (4), 26-49. https://doi.org/10.7203/JLE.4.21028 